\title{
Study of Gross Alpha and Gross Beta Radioactivities in Environmental Samples
}

\author{
S. Biswas ${ }^{1}$, J. Ferdous ${ }^{2 *}$, A. Begum ${ }^{2}$, N. Ferdous ${ }^{1}$ \\ ${ }^{1}$ Department of Physics, University of Dhaka, Bangladesh \\ ${ }^{2}$ Health Physics Division, Atomic Energy Center, Dhaka
}

Received 9 March 2015, accepted in final revised form 29 March 2015

\begin{abstract}
The main objective of this study is to determine the Gross alpha and gross beta radioactivity in environmental sample. Thirty samples of soil, water and vegetable were randomly collected from the different locations of Bheramara and Ishwardi near the proposed Rooppur Nuclear Power Plant area, Kushtia and Pabna, Bangladesh. The Gross Alpha activity under investigation ranges from 1.13 to $5.66 \mathrm{~Bq} \mathrm{~kg}^{-1}$ with an average of $2.78 \pm 0.16$ $\mathrm{Bq} \mathrm{kg}^{-1}$ for soil sample, 0.45 to $1.36 \mathrm{mBq} \mathrm{L}^{-1}$ with an average of $0.91 \pm 0.18 \mathrm{mBq} \mathrm{L}^{-1}$ for water sample, and 0.23 to $1.81 \mathrm{~Bq} \mathrm{~kg}^{-1}$ with an average of $1.0 \pm 0.11 \mathrm{~Bq} \mathrm{~kg}^{-1}$ for vegetable sample. The Gross Beta activity under investigation ranges from 30.74 to $132 \mathrm{~Bq} \mathrm{~kg}^{-1}$ with an average of $71.85 \pm 1.99 \mathrm{~Bq} \mathrm{~kg}^{-1}$ for soil sample, 61.49 to $279 \mathrm{mBq} \mathrm{L}^{-1}$ with an average of $175 \pm 4.02 \mathrm{mBq} \mathrm{L}^{-1}$ for water sample, and 305 to $1676 \mathrm{~Bq} \mathrm{~kg}^{-1}$ with an average of $930 \pm 3.27$ $\mathrm{Bq} \mathrm{kg}{ }^{-1}$ for vegetable sample. This study will help to prepare baseline data for gross alpha and gross beta radioactivity in environmental sample which will be used as finger print for the comparison of radioactivity level.
\end{abstract}

Keywords: Gross alpha and gross beta radioactivity; Environmental samples; Zinc sulfide scintillation detector; Zones (Ag).

(C) 2015 JSR Publications. ISSN: 2070-0237 (Print); 2070-0245 (Online). All rights reserved.

doi: http://dx.doi.org/10.3329/jsr.v7i1-2.22479 J. Sci. Res. 7 (1-2), 35-44 (2015)

\section{Introduction}

Radionuclides are found in air, water, soil and plant. Every day, we ingest/inhale nuclides in the air we breathe, in the food we eat and the water we drink. Radioactivity is common in the rocks and soil that makes up our planet, in the water and oceans, and even in our building materials and homes. It is just everywhere. There is no where on earth that one can get away from natural radioactivity [1]. Soil acts as a source of transfers of radionuclides through the food chain depending on their chemical properties and the

* Corresponding author: ferdous28@yahoo.com 
uptake process by the roots to plants and animals [2]; hence, it is the basic indicator of the radiological status of the environment. These radionuclides take part in several biogeochemical processes that determine their mobility and availability for biological update [3]. The major potential hazard from the natural radiation is from external exposure either by direct exposure to soil or as they enter in many building materials. Vegetables may be subjected to direct and indirect contamination of uranium series radionuclides. Use of fertilizers lead to elevation of uranium series nuclides in vegetable. Naturally occurring radio nuclides of thorium and uranium are the significant contributors of ingestion dose and are present in the biotic system of plants, animal, soil, water, air and thus in food [4]. Water contains a number of both alpha (such as ${ }^{238} \mathrm{U},{ }^{226} \mathrm{Ra}$ and ${ }^{210} \mathrm{Po}$ ) and beta emitters (such as ${ }^{40} \mathrm{~K},{ }^{228} \mathrm{Ra}$ and ${ }^{210} \mathrm{~Pb}$ ). Natural radioisotopes as ${ }^{40} \mathrm{~K}$ and the nuclides from the ${ }^{238} \mathrm{U}$ and ${ }^{232} \mathrm{Th}$ series are the greatest source of internal and external exposure in human beings. External radiation is originated from cosmic rays and terrestrial radiation, while the ingestion and inhalation of natural radionuclides lead to the doses for internal radiation. Among the radionuclides of terrestrial origin, ${ }^{40} \mathrm{~K}$ and the constituents of the ${ }^{238} \mathrm{U}$ and ${ }^{232} \mathrm{Th}$ series enter the human body largely by food and water ingestion, being the total exposure per person $0.29 \mathrm{mSv}$, of which $0.17 \mathrm{mSv}$ due to the ${ }^{40} \mathrm{~K}$ and $0.12 \mathrm{mSv}$ due to the radionuclides of the ${ }^{238} \mathrm{U}$ and ${ }^{232} \mathrm{Th}$ series [5]. The ${ }^{238} \mathrm{U}$ represents $99.28 \%$ of the natural uranium found in the earth's crust in form of uranium ores [5]. The main emitters of alpha that can be present in soil, water and vegetable are the ${ }^{238} \mathrm{U},{ }^{234} \mathrm{U},{ }^{232} \mathrm{Th},{ }^{226} \mathrm{Ra}$ and ${ }^{210} \mathrm{Po}$ and beta ${ }^{40} \mathrm{~K},{ }^{228} \mathrm{Ra}$ and ${ }^{210} \mathrm{~Pb}$ in different concentrations. The gross alpha activity is defined as the total activity of all the alpha emitters (including ${ }^{226} \mathrm{Ra}$ ) once the radon has been eliminated. The gross beta activity is the activity of all beta emitters excluding ${ }^{3} \mathrm{H}$, ${ }^{14} \mathrm{C}$ and other weak beta emitters [6]. The identification and concentration of each radionuclide present in the soil, water and vegetable requires expensive time-consuming analyses. In general, gross alpha and beta analysis, one of the simplest radio analytical procedures, is used as the first step of a screening method, for being a very fast, safe and low cost method [5]. This present study will help to prepare baseline data for gross alpha and gross beta radioactivity in environmental sample, which will be used as fingerprint for the comparison of radioactivity level.

\section{Experimental}

\subsection{Collection and preparation of samples}

In order to measure gross alpha and gross beta activity in environmental samples, thirty samples of soil, water and vegetable were randomly collected from different locations of Beamer and Shard near the proposed Roper Nuclear Power Plant area, Cushier and Pane, Bangladesh. The nuclear power plant site is located on the east bank of the Ganges River at the village Roper, in the district of Pane and approximately $170 \mathrm{~km}$ northwest of the city Dhaka, the capital of Bangladesh which is shown in Fig. 1A-C. The coordinates of the sites are: latitude $24^{\circ} 4.35^{\prime \prime}$ North and longitude $89^{\circ} 2.80^{\prime \prime}$ East. Soil samples were collected 
from different locations around the proposed site of the Plant. All the samples were collected at a depth of $0-5 \mathrm{~cm}$ from the soil-surface, surface water, vegetable. Each of the sample weight/volume was $1 \mathrm{~kg}$ for soil, 1L for water and 1.5 to $2.0 \mathrm{~kg}$ for vegetable. The samples were carried in dried acetone-cleaned polyethylene bags with sample codes and transferred to the laboratory. The samples were appropriately coded from Soil -1 to Soil10 for soil, Water-01 to Water-10 for water and Vegetable by name. The collected environmental samples were transferred to the laboratory for gross alpha and gross beta radioactivity analyses.
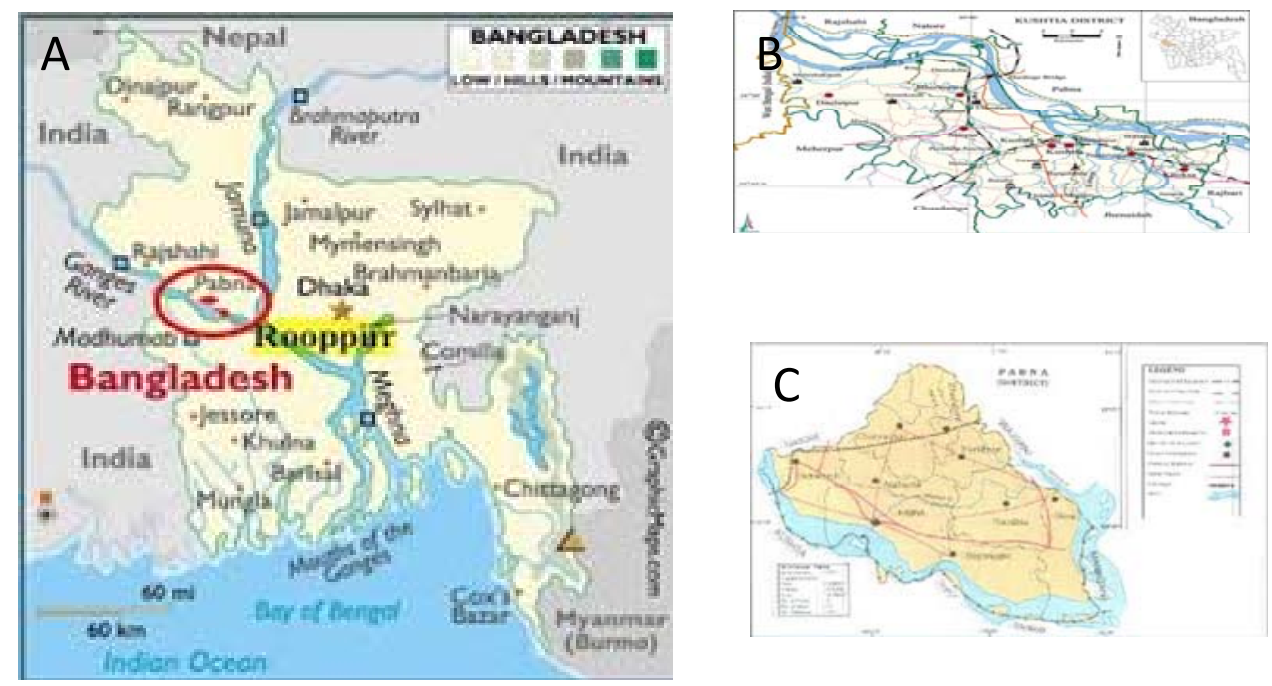

Fig.1. Location of Roper, Bangladesh (A); map of Cushier district (B); and map of Pane district (C)

\subsection{Preparation of soil and vegetable sample}

The samples were heated carefully in a muffle furnace (Carbolite type CSF 11/1). They were first heated at a low temperature and then slowly ramped upwards. The sample was dried unto $550^{\circ} \mathrm{C}$ to $600^{\circ} \mathrm{C}$ and the samples were transformed into ash. $2 \mathrm{~g}$ of ash sample was mixed with dist. water, conc. $\mathrm{HNO}_{3}$, and 3 to 5 drops of conc. Hal in a beaker. The sample was heated carefully over a hotplate. The solution was evaporated to near dryness. Again $\mathrm{HNO}_{3}$ was added and evaporated to near dryness. Then dist. water was added and slowly evaporated upto $15 \mathrm{~mL}$. Then the soil residue was separated by centrifugation. The solution was brought to a known volume, and an aliquot was transferred to a tarred planchet. Then the solution was evaporated on the planchet to dryness under an Infrared heating lamp. The heating rate was controlled so that the sample did not spatter. The planchet was allowed to cool and preserved in desiccators to avoid moisture sorption [7]. 


\subsection{Preparation of water sample}

About $1 \mathrm{~L}$ of each sample was poured into a $1 \mathrm{~L}$ beaker. $1 \mathrm{~mL}$ conc. $\mathrm{HNO}_{3}$ was added to each water sample. Subsequently, the water samples were slowly evaporated on a waterbath near to dryness (15 $\mathrm{mL}$ approximately). During evaporation, the beaker was covered with a watchglass. Then it was transferred to a 2 inch stainless steel counting planchet and dried under IR lamp and cooled. The dry residue was weighed and kept in desiccators [8].

\subsection{Zinc sulphide scintillation detector}

$\mathrm{ZnS}$ scintillation counter is a dual phosphor detector or dual scintillation detectors coupling two scintillating materials to a photomultiplier tube (PMT). These detectors are sometimes referred to as a "phoswich" (for phosphor sandwich). The MPC-2000-B-DP contains a custom designed detector with a $\mathrm{ZnS}$ layer bonded to a plastic scintillator. The combination is optically coupled to a PMT. The outermost layer detects alpha particles, and the inner layer detects beta particles. The DP (phoswich) detector offers equivalent alpha efficiency, and slightly lower beta efficiency. Background performance is very much dependent on the environment [9]. Calculations were performed on the raw data in order to convert the raw counts from counts per minute (CPM) into disintegration's per minute (DPM) and finally into units of activity per sample such as $\mathrm{Bq} \mathrm{Kg}{ }^{-1}$ and $\mathrm{Bq} \mathrm{L}^{-1}$. The dry residue of tap water samples were counted for gross alpha and gross beta activities using $\mathrm{ZnS}$ scintillation detector and gas proportional counter respectively. Known activity standard source Th-230 and Sr-90 were used for detector calibrations. The efficiency of the detector for gross alpha is $36.8 \%$ and for gross beta is $41 \%$. The counting time was $120 \mathrm{~min}$. for gross alpha and gross beta activities for each counting period. A blank planchete was used for background count. Subtraction of the background count from the sample count gives the net count of the environmental sample.

\subsection{Calculation of gross alpha/beta activity}

The activity of gross alpha/beta was calculated using the following equation:

$\mathrm{DPM}=\mathrm{NET} \_\mathrm{CPM} \times 100 / \mathrm{EFF}$

Where, DPM $=$ alpha/beta disintegration per min, NET_CPM $=$ Net alpha/beta count per min, and $\mathrm{EFF}=$ alpha/beta efficiency percent.

Error is the difference between a measured value and the true value of a quality or attribute. Thus, it is the factor that limits the precision and accuracy of the result of a measurement. 
The term net count rate associated with the activity measurement is the difference between the gross count rate of the sample (which is the summation of background count rate and sample count rate) and the background count rate. Each count rate includes standard deviation expressed as,

$\sigma= \pm \sqrt{\frac{\mathrm{As}}{\mathrm{Ts}}+\frac{\mathrm{Ab}}{\mathrm{Tb}}}$

Where, $\sigma=$ standard deviation, $A_{s}=$ sample count rate in c.p.s., $A_{b}=$ background count rate in c.p.s., $T_{s}=$ sample count time, $T_{b}=$ background count time. The measurement errors represent one- sigma uncertainties.

\section{Results and Discussions}

The measured activities of gross alpha and gross beta in soil, water and vegetable samples are given in Tables 1, 2 and 3 respectively.

\subsection{Gross alpha and gross beta activities in soil sample}

From Table 1, it is observed that the gross alpha activity ranges for soil samples from 1.13 to $5.66 \mathrm{~Bq} \mathrm{~kg}^{-1}$ with an average of $2.78 \pm 0.16 \mathrm{~Bq} \mathrm{~kg}^{-1}$. The highest gross alpha activity in Soil-06 is $5.66 \pm 0.21 \mathrm{~Bq} \mathrm{~kg}^{-1}$ which is collected from Bag Gari Bridge area and the lowest gross alpha activity in Soil-10 is $1.13 \pm 0.11 \mathrm{~Bq} \mathrm{~kg}^{-1}$ which is collected from Dhoulotpur Gachi. The gross beta activity for soil samples is from 30.74 to $132 \mathrm{~Bq} \mathrm{~kg}^{-1}$ with an average of $71.85 \pm 1.99 \mathrm{~Bq} \mathrm{~kg}^{-1}$. The highest gross beta activity found in Soil-09 sample is $132 \pm 2.07 \mathrm{~Bq} \mathrm{~kg}^{-1}$ which is collected from Golapnagor and the lowest gross beta activity found in Soil-02 sample is $30.74 \pm 1.93 \mathrm{~Bq} \mathrm{~kg}^{-1}$ which is collected from Gopinathpur middle of Bahadur and Pakshi. From Table 1, it is found that the gross beta activity in soil sample is 25 times higher than the gross alpha activity in soil sample.

\subsection{Gross alpha and gross beta activities in water sample}

The gross alpha activity for water samples is from 0.45 to $1.36 \mathrm{mBql}^{-1}$ with an average of $0.91 \pm 0.18 \mathrm{mBq} \mathrm{L}^{-1}$ as illustrated in Table 2. The highest gross alpha activities observed in Water-03 and Water-04 samples are $1.36 \pm 0.21 \mathrm{mBq} \mathrm{L}^{-1}$ which are collected from Chowton Moor, Bheramara and Bheramara 3No. Bridge, Powrashave Border. The lowest gross alpha activities in Water-09 and Water-10 are $0.45 \pm 0.13 \mathrm{mBq} \mathrm{L} \mathrm{L}^{-1}$ which are collected from Plant Area, location-(3) and Plant Area, location -(11). It is also found that the gross beta activity for water samples ranges from 61.49 to $279 \mathrm{mBq} \mathrm{L}^{-1}$ with an average of $175 \pm 4.02 \mathrm{mBq} \mathrm{L}^{-1}$. The highest gross beta activity found in Water-08 sample is $279 \pm 4.17 \mathrm{mBq} \mathrm{L}^{-1}$ which is collected from Lalon shah Bridge $1 \mathrm{Km}$ from Pabna and the lowest gross beta activity found in Water-02 sample is $61.49 \pm 3.86 \mathrm{mBq} \mathrm{L}^{-1}$ which is 
collected from Porankhali Bazar, Juniadah. The gross beta activity in water sample is higher than the gross alpha activity.

\subsection{Gross alpha and gross beta activities in vegetable sample}

From Table 3, it is observed that the gross alpha activity for vegetable samples ranges from 0.23 to $1.81 \mathrm{~Bq} \mathrm{~kg}^{-1}$ with an average of $1.0 \pm 0.11 \mathrm{~Bq} \mathrm{~kg}^{-1}$. The highest gross alpha activity in Kochu shak (Coco-yam) is $1.81 \pm 0.12 \mathrm{~Bq} \mathrm{~kg}^{-1}$ which is collected from Potirajpur, Muladhuli, Ishurdi area and the lowest gross alpha activity in Gajor (Carrot) is $0.23 \pm 0.07 \mathrm{~Bq} \mathrm{~kg}^{-1}$ which is collected from Porankhali Bazar, Juniadah. . It is also found that the gross beta activity for vegetable samples ranges from 305 to $1676 \mathrm{~Bq} \mathrm{~kg}^{-1}$ with an average of $930 \pm 3.27 \mathrm{~Bq} \mathrm{~kg}^{-1}$. The highest gross beta activity found in Kacha kola (Plantain) sample is $1676 \pm 3.89 \mathrm{~Bq} \mathrm{~kg}^{-1}$ which is collected from Dharampur Gov. Primary School Bheramara and the lowest gross beta activity found in Kochu shak (Coco-yam) sample is $305 \pm 2.72 \mathrm{~Bq} \mathrm{~kg}^{-1}$ which is collected from Potirajpur, Muladhuli, Ishwrdi. From Table 3, it is observed that the gross alpha activity in vegetable sample is much lower than the gross beta activity. Use of fertilizer can also increase the concentration of beta radioactivity. Naturally ${ }^{40} \mathrm{~K}$ also increases the gross beta radioactivity,

Table 1. Gross alpha and gross beta activities in soil samples.

\begin{tabular}{cccc}
\hline Location of sample collection & Sample code & $\begin{array}{c}\text { Gross alpha activity } \\
\mathrm{Bq} \mathrm{kg}^{-1}\end{array}$ & $\begin{array}{c}\text { Gross beta activity } \\
\mathrm{Bq} \mathrm{kg}^{-1}\end{array}$ \\
\hline $\begin{array}{c}\text { Opposite side of the Padma } \\
\text { river and middle of two bridges } \\
\text { Gopinathpur, middle of }\end{array}$ & Soil-01 & $1.81 \pm 0.14$ & $42.48 \pm 1.95$ \\
Bahadur and Pakshi & Soil-02 & $2.94 \pm 0.16$ & $30.74 \pm 1.93$ \\
Char Gopinathpur & Soil-03 & $2.27 \pm 0.15$ & $69.18 \pm 1.99$ \\
Gopinathpur Centre & Soil-04 & $4.08 \pm 0.18$ & $61.08 \pm 1.97$ \\
Golapnagor & Soil-05 & $2.27 \pm 0.15$ & $106 \pm 2.04$ \\
Bag Gari Bridge area & Soil-06 & $5.66 \pm 0.21$ & $48.54 \pm 1.97$ \\
Bangir Moor, Bahadurabadh & Soil-07 & $2.72 \pm 0.16$ & $78.68 \pm 2.00$ \\
Madhabpur & Soil-08 & $2.72 \pm 0.16$ & $76.66 \pm 2.00$ \\
Thakur Char Dhoulatpur Gov. & Soil-09 & $1.81 \pm 0.14$ & $132 \pm 2.07$ \\
Primary School & Soil-10 & $1.13 \pm 0.11$ & $73.63 \pm 1.99$ \\
Dhoulotpur Gachia & Average & $2.78 \pm 0.16$ & $71.85 \pm 1.99$ \\
& Maximum & $5.66 \pm 0.21$ & $132 \pm 2.07$ \\
& Minimum & $1.13 \pm 0.11$ & $30.74 \pm 1.93$ \\
\hline
\end{tabular}

Table 2. Gross alpha and gross beta activities in water samples.

\begin{tabular}{cccc}
\hline Location of sample collection & Sample code & $\begin{array}{c}\text { Gross alpha activity } \\
(\mathrm{mBq} \mathrm{L})\end{array}$ & $\begin{array}{c}\text { Gross alpha } \\
\text { activity }\left(\mathrm{mBq} \mathrm{L}^{-1}\right)\end{array}$ \\
\hline $\begin{array}{c}\text { Gopinathpur Centre } \\
\text { Porankhali Bazar, Juniadah }\end{array}$ & Water- 01 & $0.91 \pm 0.20$ & $132 \pm 3.96$ \\
Chowton Moor, Bheramara & Water- 02 & $0.91 \pm 0.17$ & $61.49 \pm 3.86$ \\
& Water- 03 & $1.36 \pm 0.21$ & $269 \pm 4.15$
\end{tabular}




\begin{tabular}{cccc}
\hline Location of sample collection & Sample code & $\begin{array}{c}\text { Gross alpha activity } \\
\left(\mathrm{mBq} \mathrm{L}^{-1}\right)\end{array}$ & $\begin{array}{c}\text { Gross alpha } \\
\text { activity }\left(\mathrm{mBq} \mathrm{L}^{-1}\right)\end{array}$ \\
\hline $\begin{array}{c}\text { Bheramara 3no Bridge, } \\
\text { Powrashave Border } \\
\text { Beside of Chandipur G.K }\end{array}$ & Water- 04 & $1.36 \pm 0.21$ & $223 \pm 4.09$ \\
$\begin{array}{c}\text { Project } \\
\text { Naymail, Kachari, Mirpur }\end{array}$ & Water- 05 & $0.91 \pm 0.20$ & $225 \pm 4.09$ \\
$\begin{array}{c}\text { Thana } \\
\text { Pabna 39 km Mile }\end{array}$ & Water- 06 & $0.91 \pm 0.20$ & $73.63 \pm 3.88$ \\
Board,Mirpur Thana & Water- 07 & $0.91 \pm 0.17$ & $211 \pm 4.07$ \\
Lalon shah Bridge 1Km Pabna & Water- 08 & $0.91 \pm 0.17$ & $279 \pm 4.17$ \\
Plant area, location-(3) & Water- 09 & $0.45 \pm 0.13$ & $190 \pm 4.04$ \\
Plant area, location (11) & Water- 10 & $0.45 \pm 0.13$ & $81.72 \pm 3.89$ \\
& Average & $0.91 \pm 0.18$ & $175 \pm 4.02$ \\
& Maximum & $1.36 \pm 0.21$ & $279 \pm 4.17$ \\
& Minimum & $0.45 \pm 0.13$ & $61.49 \pm 3.86$ \\
\hline
\end{tabular}

Table 3. Gross alpha and gross beta activities in vegetable samples.

\begin{tabular}{|c|c|c|c|}
\hline Location of sample collection & Sample name & $\begin{array}{l}\text { Gross alpha activity } \\
\left(\mathrm{Bq} \mathrm{kg}^{-1}\right)\end{array}$ & $\begin{array}{c}\text { Gross beta activity } \\
\mathrm{Bq} \mathrm{kg}^{-1}\end{array}$ \\
\hline $\begin{array}{c}\text { Thakur Chair Dhoulatpur } \\
\text { Gov. Primary School }\end{array}$ & $\begin{array}{c}\text { Foolkopi } \\
\text { (Cauliflower) }\end{array}$ & $1.59 \pm 0.13$ & $1471 \pm 3.74$ \\
\hline $\begin{array}{c}\text { Jagoshor, Porankhali } \\
\text { Bheramara }\end{array}$ & $\begin{array}{l}\text { Kacha papay } \\
\text { (Green papaya) }\end{array}$ & $0.45 \pm 0.09$ & $1367 \pm 3.66$ \\
\hline $\begin{array}{l}\text { Dharampur Gov. Primary } \\
\text { School Bheramara }\end{array}$ & $\begin{array}{l}\text { Kacha kola } \\
\text { (Plantain) }\end{array}$ & $1.13 \pm 0.12$ & $1676 \pm 3.89$ \\
\hline Porankhali Bazar, Juniadah & Gajor (Carrot) & $0.23 \pm 0.07$ & $904 \pm 3.28$ \\
\hline $\begin{array}{l}\text { Health and Family Welfare } \\
\text { Centre, Bheramara }\end{array}$ & Begun (Brinjal) & $1.59 \pm 0.12$ & $1660 \pm 3.87$ \\
\hline Kharara, Mirpur Thana & $\begin{array}{l}\text { Kakrol (Teasle } \\
\text { Gourd) }\end{array}$ & $0.45 \pm 0.10$ & $332 \pm 2 . .75$ \\
\hline Plant area, location-(3) & Mula (Radish) & $1.81 \pm 0.14$ & $807 \pm 3.20$ \\
\hline Plant area, location-(4) & $\begin{array}{l}\text { Lau shak (Bottle } \\
\text { Gourd) }\end{array}$ & $0.45 \pm 0.10$ & $426 \pm 2.84$ \\
\hline $\begin{array}{l}\text { Potirajpur, Muladhuli, } \\
\text { Ishwrdi }\end{array}$ & $\begin{array}{l}\text { Kochu shak } \\
\text { (Coco-yam) }\end{array}$ & $1.81 \pm 0.12$ & $305 \pm 2.72$ \\
\hline \multirow[t]{4}{*}{$\begin{array}{l}\text { PDB Colony, Joynagar, } \\
\text { Ishurdi }\end{array}$} & $\begin{array}{l}\text { Tamak (Leaf } \\
\text { Tobacco) }\end{array}$ & $0.45 \pm 0.10$ & $349 \pm 2.77$ \\
\hline & Average & $1.0 \pm 0.11$ & $930 \pm 3.27$ \\
\hline & Maximum & $1.81 \pm 0.12$ & $1676 \pm 3.89$ \\
\hline & Minimum & $0.23 \pm 0.07$ & $305 \pm 2.72$ \\
\hline
\end{tabular}

A comparison of gross alpha and gross beta radioactivity in soil samples of Bangladesh with different countries around the world is shown in Table 4. Compared to other countries like India, Serbia, Nigeria and Malaysia, the results of gross alpha and 
gross beta activities in soil sample of Bangladesh are lower [4,6.10,12-14]. A comparison of gross alpha and gross beta radioactivities in water samples of Bangladesh with different countries around the world is given in Table 5.

Table 4. Comparison of gross alpha and gross beta radioactivities in soil sample.

\begin{tabular}{|c|c|c|c|}
\hline Country & Type of soil & Gross alpha $\left(\mathrm{Bq} \mathrm{kg}^{-1}\right)$ & Gross beta $\left(\mathrm{Bq} \mathrm{kg}^{-1}\right)$ \\
\hline $\begin{array}{l}\text { Rajasthan } \\
\text { (India) }\end{array}$ & Surface & $175-2260$ & \\
\hline Serbia & Power Plant Area & $66.7-102.4$ & $285.7-607.4$ \\
\hline Nigeria & Oil producing fields & $152.11-322$ & $311.15-615.5$ \\
\hline Nigeria & $\begin{array}{l}\text { Chemical fertilizers } \\
\text { 1. Single super phosphate } \\
\text { 2. NPK } \\
\text { Agricultural farm soils } \\
\text { 1. North } \\
\text { 2. South }\end{array}$ & $\begin{array}{c}60.0-100.0 \\
20.0-90.0 \\
\\
8.0-40.00 \\
10.00-20.00\end{array}$ & $\begin{array}{c}1340.0-1440.0 \\
2410.0-4560.0 \\
360.0-570.0 \\
200.0-230.0\end{array}$ \\
\hline Malaysia & Ground Soils & $15-9634$ & $142-6173$ \\
\hline $\begin{array}{c}\text { Bangladesh } \\
\text { (Present Study) }\end{array}$ & Surface Soils & $1.13-5.66$ & $30.74-132$ \\
\hline
\end{tabular}

Table 5. Comparison of gross alpha and gross beta radioactivities in water sample.

\begin{tabular}{|c|c|c|c|}
\hline Country & Type of Water & Gross alpha $\left(\mathrm{Bq} \mathrm{L}^{-1}\right)$ & Gross beta $\left(\mathrm{Bq} \mathrm{L}^{-1}\right)$ \\
\hline Nigeria & $\begin{array}{l}\text { 1. Dug well water } \\
\text { 2. Rivers state } \\
\text { 3.Ground } \\
\text { water(Tap) }\end{array}$ & $\begin{array}{c}0.22 \times 10^{-3}-2.99 \times 10^{-3} \\
0.11-1.21 \\
0.02-35.1\end{array}$ & $\begin{array}{c}0.06 \times 10^{-3}-0.58 \times 10^{-3} \\
0.21-2.03 \\
0.70-151.2\end{array}$ \\
\hline Turkey & $\begin{array}{l}\text { 1. Ground water } \\
\text { 2. Thermal waters }\end{array}$ & $\begin{array}{l}0.08-0.38 \\
0.09-2.58\end{array}$ & $\begin{array}{l}0.12-3.47 \\
0.25-2.61\end{array}$ \\
\hline Tamil Nadu, India & Drinking water & $0.07-0.28$ & $0.76-1.28$ \\
\hline Brazil & $\begin{array}{c}\text { Surface, } \\
\text { Underground, } \\
\text { Drinking waters }\end{array}$ & $0.02-0.08$ & $0.01-3.0$ \\
\hline Dhaka, Bangladesh & Tap water & $1.88 \times 10^{-3}-8.16 \times 10^{-3}$ & $3.76 \times 10^{-3}-29.3 \times 10^{-3}$ \\
\hline Dhaka, Bangladesh & Bottled water & $1.4 \times 10^{-3} \pm 0.7 \times 10^{-3}$ & $76.0 \times 10^{-3} \pm 9.8 \times 10^{-3}$ \\
\hline $\begin{array}{c}\text { Bangladesh } \\
\text { (Present study) }\end{array}$ & Surface water & $0.45 \times 10^{-3}-1.36 \times 10^{-3}$ & $0.061-0.279$ \\
\hline
\end{tabular}

Comparing the values of gross alpha and gross beta activities with others, it is observed that gross alpha and gross beta activities of surface water samples in Bangladesh are lower than surface, underground and drinking water samples of other countries of the world like Nigeria, Turkey, India and Brazil $[5,6,15]$. It is also observed that the gross alpha and gross beta activities in surface water samples in Bangladesh are lower than the tap and bottled water samples of Bangladesh. The results showed that the activity 
concentrations of gross alpha and gross beta in surface water samples did not exceed WHO recommended levels and were comparable with the data available in other parts of the world [17].

A comparison of gross alpha and gross beta radioactivities in vegetable samples of Bangladesh with different countries around the world is shown in Table 6.

Table 6. Comparison of gross alpha and gross beta radioactivities in vegetable samples.

\begin{tabular}{cccc}
\hline Country & Type of sample & $\begin{array}{c}\text { Gross alpha } \\
\mathrm{Bq} \mathrm{kg}^{-1}\end{array}$ & $\begin{array}{c}\text { Gross beta } \\
\mathrm{Bq} \mathrm{kg}^{-1}\end{array}$ \\
\hline Rajasthan (India) & Plant & $48.0-477.0$ & $124.34-790.58$ \\
Ghana & Medicinal Plants & $11.73-132.67$ & $10946.0 \pm 583.0$ \\
fouthwest India & food crops & $497.0 \pm 72.0$ & $305-1676$ \\
Bangladesh & Vegetable & $0.23-1.81$ & \\
(Present study) & & & \\
\hline
\end{tabular}

In vegetable samples of Bangladesh the gross alpha and gross beta activities are lower than other plants and crop samples from the different parts of India. But gross alpha and gross beta concentration of vegetable samples are higher than the medicinal plant samples of Ghana $[10,16]$.

\section{Conclusion}

Natural soil, water and vegetables are not completely free from radioactive isotopes due to the presence of beta and alpha emitters from the natural decay series of uranium, thorium and actinium and other single isotopes such as ${ }^{40} \mathrm{~K}$. The main alpha emitters are ${ }^{238} \mathrm{U},{ }^{234} \mathrm{U}$, ${ }^{232} \mathrm{Th},{ }^{226} \mathrm{Ra}$ and ${ }^{210} \mathrm{Po}$ and the main beta emitters are ${ }^{40} \mathrm{~K},{ }^{228} \mathrm{Ra},{ }^{210} \mathrm{~Pb}$ that can be present in environmental samples in different concentrations. From this study it is observed that the gross beta activity is higher than the gross alpha activity in the collected environmental (soil, water, vegetable) samples from different locations of Bheramara and Ishwardi near the proposed Rooppur Nuclear Power Plant area, Kushtia and Pabna of Bangladesh. In case of soil and vegetable samples of the present study the concentration of gross alpha and gross beta activities are typically lower than the other countries of the world. The gross alpha and gross beta activities in water sample are lower than the recommended value of WHO. There is a limited data for gross alpha and gross beta in Bangladesh and this study will help to provide baseline data for gross alpha and gross beta in environmental samples of Bheramara and Ishwardi near the proposed Rooppur Nuclear Power Plant area, Kushtia and Pabna, Bangladesh that can be used to evaluate the possible changes and the radiological impact on the public health in future.

\section{References}

1. International Atomic Energy Agency, Measurement of Radionuclides in Food and the Environment, Technical Series No. 295, Vienna, (1989).

2. A. Jabbar, M. Tufail, W. Arshed, A. S. Bhatti, S. S. Ahmad, P. Akhter, and M. Dilband, Isotop. Environ. Health Studies 46, 495 (2010). 
3. L. J. Mandić, R. Dragović, and S. Dragović, J. Geochem. Explor. 105, 43 (2010).

4. G. Shanthi, C. G. Maniyan, G. A. G. Raj, and J. T. T. Kumaran, Cur. Sci. 97, 1331 (2009).

5. L. S. Silva and B. R. S. Pecequilo, Radioprotection 46, S63 (2011).

6. M. J. Ferdous, M. M. Rahman, and A. Begum, Sri Lankan J. Phys. 13, 01 (2012).

7. W. P. Brug, Laboratory Method for Gross Alpha and Beta Activity Determination (Los Alamos National Laboratory, Los Alamos, New Mexico, 1997).

8. U.S. EPA National Exposure Research Laboratory, EPA 900, Gross Alpha and Gross Beta Radioactivity in Drinking Water (US Gov. Printing Office, 1980).

9. Manual MPC-2000, Gross Alpha /Beta Counter (Protean Instrument Corporation) www.proteaninstrument.com

10. D. B. Pathak and A. Pathak, Int. J. Sci. Eng. Res. 3, 65 (2012).

11. N. Sarap, V. Kraisnik, and M Jankovic, in Agrosym Jahorina - Proc. of $3^{\text {rd }}$ Int. Sci. Symp. (Faculty of Agriculture, University of East Sarajevo, Bosnia, 2012) pp. 316.

12. U. L Anekwe, G. O Avwiri, and O. E. Abumere, Am. J. Sci. Ind. Res. 4, 546 (2013).

13. N. N. Jibiri and K. P. Fasae, Nat. Sci. I.5, 71 (2013).

14 S. K. Lee, H. Wagiran, A. T. Ramli, Radiat. Prot. Dosim. 156, 52 (2013).

15. S.Turhan, E. Ozçitak, H.Taşkin and A. Varinlioğlu, Water Res. 47, 3103 (2013).

16. L. E. O. Tettey-Larbi, C. Darko, A. A. Schandorf, F. S. Appiah, A. Faanu, D. K. Okoh, H. Lawluvi, B. K. Agyeman, C. Kansaana, P. A. Amoah, R. K. Osei, R. Agalga, and S. Osei, Int. J. Sci. Technol. 3, 42 (2013).

17. Guidelines for Drinking-water Quality, First Addendum to 3rd edition (WHO, 2006) 1, Chapter-9. 